https://doi.org/10.18485/iipe_60nam.2021.ch21

\title{
BRAZIL AND THE NON-ALIGNED MOVEMENT: PARALLEL PATHS, COMMON GOALS
}

\begin{abstract}
Beatriz BISSIO ${ }^{1}$
Abstract: In the first post-war decades, in the second half of the $20^{\text {th }}$ century, when anti-colonialist consciousness and the construction of new states was advancing in Africa and Asia, seeking their own autonomous space in the bipolar world of the time, Latin America turned to the study of the problems of underdevelopment and sought ways to overcome them. This gap in interests and the hemispheric security doctrine imposed by the United States partly explains the initial lack of support from Latin American countries for the Non-Alignment proposal. Brazil was no exception, but it always maintained an active and proactive stance on economic issues, which led to a de facto rapprochement with the NAM postulates. Brazil's boldest foreign policy stance was adopted in the $21^{\text {st }}$ century when progressive governments led by the Workers' Party committed themselves to the BRICS strategy. That audacity explains much of what the country is experiencing at the moment due to the strong reaction that this initiative provoked in Washington and the domestic ruling classes.

Key words: Bandung, Non-Alignment, Latin America, Brazil, US hegemony, Monroe Doctrine.
\end{abstract}

\section{Introduction}

In this second decade of the $21^{\text {st }}$ century, it is important to review some of the processes that marked the $20^{\text {th }}$ century and analyse them in light of today's problems. Today we see a clear tendency towards the formation of

\footnotetext{
${ }^{1}$ Associate Professor at the Department of Political Science and of the Post-Graduate Program in Comparative History and Coordinator of the Research Centre for Interdisciplinary Studies on Africa, Asia and South-South Relations, Federal University of Rio de Janeiro.

E-mail: bbissio@ufrj.br
} 
a multipolar world, with Russia and China as major players. And, more than this, we are witnessing the progressive decline of the West that will lose more than half of its economic importance in the next 15 years. In the new geopolitical landscape, the Asian continent is emerging as the scientific and technological innovation world centre, with China as its locomotive, and this provoked what is being called the Cold War 2.0 in the media and some academic circles as a response from the United States. Although the concept is not entirely appropriate, it is useful for describing the growing confrontation between the United States and China, within the framework of a concomitant strong aggressiveness of the US establishment against Russia. With this framework in mind, it is interesting to review some episodes of the $20^{\text {th }}$ century that allow us to evaluate the changes that are better understood if interpreted in a long-term perspective rather than a short-term view.

Historians and political leaders who study the $20^{\text {th }}$ century have no hesitation in placing the Non-Aligned Movement foundation in Belgrade in 1961 as one of the milestones on the global stage. Neither do they have doubts in pointing out that the movement's embryo should be traced to the 1955 Bandung Afro-Asian Conference (18 to 24 April 1955) which brought together leaders from some thirty Asian and African nations, responsible for the destiny of 1.350 million human beings! These leaders were eager to make their voices heard for the first time, and they did so in the challenging context of an already evident Cold War scenario because they wanted to defend their interests while remaining independent of both ideological blocs. The Bandung stated aims were "to promote Afro-Asian economic and cultural cooperation to oppose colonialism and imperialism, particularly attempts by the United States and the Soviet Union to extend their influence over the Global South in the post-war global order". Bandung was more about that. It was an attempt to establish a common ideology among anticolonial nations, which could replace the Cold War system dominated by the ideological conflict between communism and capitalism (Lee, 2011, p. 145). This diplomatic debut of the Global South had been patiently prepared through the articulations of young Asian countries within the also young United Nations. The UN Charter included the clause in defence of the nations' right to self-determination, which had been inherited from the failed League of Nations. In the context of the post-WWI period, it had had no meaning for the subjugated South because Great Britain and France, victors of the conflict, were also the two most important colonial empires. But in the post-World War II scenario, with the United States and the Soviet Union elevated to the status of dominant superpowers, this clause, together with 
the 1948 Universal Declaration of Human Rights, provided a solid legal underpinning for the decolonisation process. By consecrating the emergence of the Non-Aligned Movement and the concept of the Third World, the Bandung meeting symbolically represented the moment in which a significant sector of humanity became aware of its role and made its voice heard. Richard Wright, a journalist who became well-known after his novel Native Son (1940), which became the first book by an African-American writer to be selected by the Book-of-the-Month Club, wrote The Colour Curtain. After attending a conference in Bandung, he wrote: "Despised, insulted, hurt, disenfranchised - in short, the informers of the human race met. Here were class and racial and religious consciousness on a global scale. Who had thought of organising such a meeting? And what did these nations have in common? Nothing, it seemed to me, but what their past relationship to the Western world had made them feel. This meeting of the rejected was in itself a kind of judgment upon the Western world!" (Wright, 1956). It was true that there were differences among the participants. But guided by the idea of creating a space of their own - an imagined community? - In the bipolar world of the period, this group of nations identified ten principles that guided their action in favour of the promotion of peaceful coexistence. And through these principles, the "spirit of Bandung" marked the process of liberation from the colonial world and determined the path for the international insertion of the countries that formed the Non-Aligned Movement, with an explicit condemnation of racism, colonialism, and imperialism and a clear definition in favour of respect for the sovereignty and territorial integrity of all nations and, consequently, of non-intervention in the internal affairs of other countries. The "Ten Principles for Peace" were based on the "Five Principles of Peaceful Coexistence" as defined in the declaration signed by India and China, with the presence of Myanmar, in 1954, to overcome their differences and focus on the defence of sovereignty and peace, non-aggression and non-interference in the internal affairs of other countries. Bandung gave visibility to the struggle of the peoples of Africa and Asia for their independence, and this visibility was transformed into a political and diplomatic force with the massive incorporation of new states into the UN, especially after 1960 when 16 African states were admitted. This new correlation of forces contributed to the adoption, in December of the same year, of the Declaration on the Granting of Independence to Colonial Countries and Peoples (GAR 1514), placing the world institution at the forefront of international support for the struggle of liberation movements. The work of African countries to unite and formulate common interests and demands proved effective with the creation of the 
Organisation of African Unity in 1963, based in Addis Ababa, Ethiopia, which began to coordinate actions at the UN with the countries of the Arab League, which had been founded in 1945, and was particularly active when the rights of the Palestinian people were at stake. Efforts to achieve closer unity did not achieve the same result in the case of Asia, as border issues maintained tensions between China and India. But despite some foreseeable differences, in a Cold War scenario between the two superpowers, the African and Asian countries were fighting for their structuring as forces with their agendas, independent of the two blocs. However, it was evident that many of these countries maintained a relatively high degree of dependence on one or the other super-power in various fields, especially economic and technological. Inspired by the Bandung success, two important African and Asian leaders, Gamal Abdel Nasser of Egypt and Jawaharlal Nehru, of India, decided to follow up the conference determinations and began a series of meetings and negotiations. A lucky coincidence had brought Egypt and India closer to Yugoslavia, which was seeking to define its new status on the world stage in the aftermath of its break with the Soviet Union. In 1950 these three countries converged in the United Nations Security Council as non-permanent members. This conviviality paved the way for a long-term partnership, facilitated by Yugoslavia's intensive lobbying in the UN on issues of interest to African and Asian countries. It is interesting to remember that, "in the months following Bandung, Tito was visited by both $\mathrm{U} \mathrm{Nu}$ and Nehru, and in December 1955 he made official state visits to Egypt and Ethiopia. Yugoslavia was also re-elected to the Security Council at the end of 1955" (Alden, Morphet and Vieira, 2013, p. 143).

Another important fact that had brought Yugoslavia closer to the leaders responsible for organising the Bandung Conference was Tito's visit to Southeast Asia in December 1954, when Yugoslavia subscribed to the principles of the Panch Shila - cited in the peace and security agreements signed between India and China, in the figures of Nehru and Zhou En-lai, in June of the same year. That rapprochement was strengthened after the success of the Bandung Conference and created the conditions for the meeting on the Brioni Islands between Tito, Nasser, and Nehru in June 1956, shortly before the nationalization of the Suez Canal.

This relationship which strengthened through the work at the United Nations and on various visits enabled Tito, Nasser and Nehru to succeed in their aim to call for the Heads of State Summit Conference to be held in the city of Belgrade, 1-6 September 1961. Six years after the Bandung Conference, this meeting formally launched the foundations of the Non- 
Aligned Movement, which was born with a broad representation as new countries had gained independence in the period. There were 28 countries represented in Belgrade, of which 25 were full members and three had observer status; among the full members there was only one Latin American country, Cuba, whose revolution triumphed two years earlier. The selfdetermination of people, the rejection of multilateral military pacts, the condemnation of apartheid, the struggle against imperialism in all its manifestations, non-intervention in the internal affairs of States, the strengthening of the UN, have been strategic themes in the Non-Aligned Movement agenda since its founding in Belgrade.

\section{Latin America and Non Alignment}

This introduction allows us to understand the reasons for Latin America's absence from the Bandung Conference and its very limited participation in Belgrade - a situation that was repeated in the following conferences, only partially altered in the 1970s. Latin America's history and geography have placed some constraints on its performance on the world stage. Let us not forget that since the early days of its life as an independent nation, the United States considered Latin America as its "backyard", an ideal space in which to exercise its dominion. The Mexicans have an amusing expression in this respect: "Poor Mexico, so far from God and so close to the United States!" The expression "Manifest Destiny" illustrates the perception of the United States as having been elected by God to expand its influence and to govern the world. Originally used in political propaganda in the $19^{\text {th }}$ century, "Manifest Destiny" ended up becoming synonymous with the US global ambitions. A specific example of this notion is the Monroe Doctrine, declared by President James Monroe in his annual message to the US Congress on 2 December 1823. This doctrine expressed in diplomatic terms old aspirations of the North-American society and has had enormous influence on American foreign policy since then. The author of this doctrine was Monroe's Secretary of State, John Quincy Adams. The doctrine declared: "The occasion has been judged proper for asserting, as a principle in which the rights and interests of the United States are involved, that the American continents, by the free and independent condition which they have assumed and maintain, are henceforth not to be considered as subjects for future colonisation by any European powers". A formula more succinct and direct of the Doctrine is "America for the North Americans". Coherent with this perception of their manifest destiny to dominate the whole American continent, the governments of the United States, even when 
having different opinions on internal policy, have over time agreed on their external policy, and have done everything to keep Latin America subjugated. One of the ways of implementing this has always been to impede the integration of Latin American nations that would have made them more able to resist US incursions (militarily and economically). Another way has been to maintain a "hemispheric defence policy", according to the Monroe Doctrine, expressed in the Inter-American Treaty of Reciprocal Assistance, IATR, signed in 1947, in the city of Rio de Janeiro. IATR is a mutual defence treaty between the United States and the Latin American countries, whose central principle was that an attack against one of the members will be considered an attack against all. In its origin, the hypothesis of a conflict was designed according to the parameters of the Cold War, with the USSR as the enemy par excellence. But with the victory of the Cuban revolution in 1959, the US gave new content to the concept of hemispheric security: the enemy was inside the countries of the region, and the Latin American Armed Forces would no longer fight against the Soviet army, helping the US in the hypothetical scenario of an invasion, but against the enemies (communists) infiltrated in their countries. Since then, all means - legal and illegal - were used to impede the initiatives of the Latin American people for change and to defeat the leaders and the progressive parties aiming to govern independently and, consequently, to define their sovereign position in the world. The dictatorship cycles in Brazil, Argentina, Chile, Uruguay, Paraguay, Bolivia, Guatemala, El Salvador, and Nicaragua in the $60 \mathrm{~s}, 70 \mathrm{~s}$, and $80 \mathrm{~s}$, and the Cuba blockade are painful examples of this policy but certainly not the only ones.

Accordingly, Latin America's international relations have sought to respond to three basic, closely related challenges: finding mechanisms to ensure autonomy (an issue that has led to the theorization of the centreperiphery relationship); the search for ways to ensure development and to achieve these two goals despite the difficult relationship with the United States. In this regard, it is important to remember that Latin America has been historically divided between elites who incorporate the worldview of the developed countries and peoples who fight for a sovereign insertion on the world map. This situation has provoked debates about the definition of the region's own identity: does Latin America belong to the West or the Global South? This division, with political and diplomatic effects, can be observed when studying Latin America's performance in the United Nations, particularly in the 1950s-70s when ECOSOC and the G-77, for example, were being organised. The complicated relationship with the US and the historical gap between Latin America's colonial experience and the rest of the South 
partly explains the cool reception of the Bandung message in the region and the slow incorporation of "Third Worldism", even among the most progressive governments. At a time when the Asian and African countries were taking their first steps towards independence and were beginning to discuss how to organise themselves to satisfy the repressed and fair aspirations of their populations, in the 1950s and 1960s, Latin America already had more than a century of experience in this field and was looking for answers to the challenges imposed by underdevelopment. Priorities were focused on economic issues, including regional economic integration, quite a realistic option in the face of the difficulty imposed by Washington on any kind of non-hemispheric alliance. However, between 1973 and 1983 eight Latin American countries - Argentina, Bolivia, Chile, Colombia, Ecuador, Nicaragua, Panama and Peru - joined the Non-Aligned Movement (NAM) as full members. If that happened, it is because over a decade some changes had taken place in the region, and one of them was the growing mistrust of the Inter-American Treaty of Reciprocal Assistance, which implicitly implied their acceptance of the military alliance with the United States. (When Cuba joined the Non-Aligned Movement in 1961, it had already broken off diplomatic relations with the United States after the April 1961 Bay of Pigs or Girón Beach invasion, financed by Washington). On the other hand, it was not until the 1970s that the Non-Aligned Movement began to formally discuss economic issues on which Latin America had been working intensively, as aforementioned, through the Economic Commission for Latin America. This was an important factor in attracting the attention of some Latin American countries with progressive governments towards nonalignment. But the fact that the countries that joined the NAM sought, through this initiative, to show greater autonomy vis-à-vis the United States was also decisive. The historical experience of the hemispheric alliance had proved highly unsatisfactory to their interests. The definitive watershed for these governments was the support given by the United States to Britain in 1982 during the Falklands War (when Argentina tried to regain sovereignty over the archipelago it had always considered part of its territory). The attitude of the United States in that war was interpreted by Latin Americans as a betrayal of the doctrine of hemispheric security and as the de facto declaration of nullity of the TIAR, whose clauses indicated that the United States should stand by the Argentineans in defence of their sovereignty. 


\section{The Brazilian perspective - the First period ${ }^{2}$}

In Brazil, where the colonisers did not find strongly structured societies, as in Peru or Mexico, the economy inherited from the colonial period remained almost unchanged for decades, external market-oriented. By choosing to adapt to the demands of the metropolitan centres and maintaining a neocolonial production structure, the country stagnated, despite its potential. But since the 1950s, new political and social forces were looking for ways to overcome underdevelopment. The debate on economic issues was centralised by the Higher Institute of Brazilian Studies (ISEB). Created by the government in 1955, ISEB was aimed at studying the Brazilian reality and allowing the incentive and promotion of national development. During the Juscelino Kubitschek administration, a stage in which Brazil accelerated its industrialisation with strong state investment, ISEB was responsible for the elaboration of a project that became known as "national-developmentist". The proposal was that a state-led revolution was needed to structurally transform the economy and enable the country to overcome underdevelopment. This period coincided with the intense activity of the UN Economic Commission for Latin America (UNECLA), under the leadership of Raul Prebisch. Several Brazilians were prominent architects of UNECLA thinking, in particular Celso Furtado. And it is important to mention that the dependency theory was also developed by Brazilians, living in Santiago, Chile, at that time. Many Latin American countries were contributing at the UN level with the economic discussions. In 1961, Argentina sponsored a resolution at the summer meeting of the UN Economic and Social Council (ECOSOC) calling for international conferences to discuss solutions for trade problems faced by the less developed countries (Stanford, 1976). ${ }^{3}$ Some months later, in December 1961,

\footnotetext{
${ }^{2}$ Brasil as the South American "giant" was never a member of the Non-Aligned Movement, but in its diplomatic actions it defended positions close to those of the movement, particularly in relation to economic demands.

${ }^{3}$ Latin American countries were challenged by the difficulties imposed by the global economic power structure on their aspiration to industrialise their raw materials. Latin America, like other Third World regions, continued to export mainly commodities. In the 1970s, raw materials account for more than $60 \%$ of developing countries' exports, and some of them were heavily dependent on a single commodity. For example, in 1975, crude oil accounted for more than $90 \%$ of the exports of Iran, Iraq, Libya, Nigeria, and Saudi Arabia; more than 50\% of those of Algeria, Ecuador, Gabon, Indonesia, Kuwait, Syria, and Venezuela.
} 
the UN General Assembly designated the 1960s as the "United Nations Development Decade" and international trade was defined as the "primary instrument for economic development". In July 1962, eight Latin American countries attended the Cairo Conference on the Problems of Economic Development, four as the participants - Bolivia, Brazil, Cuba, and Mexico - and four as the observers - Chile, Ecuador, Uruguay, and Venezuela. Cooperation among developing countries was a main issue during the conference and the participants "were invited to work closely in the UN and other international bodies to ensure economic progress" (Alden, Morphet and Vieira, 2013, p. 53). When the United Nations Secretary-General consulted governments on the advisability of holding an international conference on international trade problems, the favourable reactions were impressive. The first UN Conference on Trade and Development (UNCTAD) met in Geneva in March-June 1964 and was preceded by Asian, African, and Latin American regional conferences. Its chair was Raul Prebisch who defended the proposal of a permanent organisation based on periodical conferences. Latin Americans and Afro-Asian countries voted together in favour of the idea, confident that this new body would be vital for the defence of their common interests. The UNCTAD was established as an organ of the UN General Assembly, institutionalised by Resolution 1995 (XIX) to meet every four years, establishing a permanent secretariat based in Geneva and offices in New York and Addis Ababa. Since then, the political agenda of the South was promoted by the Non-Aligned Movement and the economic agenda was propelled by the newly organised Group of $77(\mathrm{G}-77)^{4}$ and the UNCTAD.

The role of leadership proved to be crucial in formulating the institutions and outlooks of the South, with Yugoslavia, India, and Egypt playing a seminal role in the creation of the Non-Aligned Movement and Latin American states in the creation of G77. At the same time, through collective mobilization, Southern interests were embedded in specific policies (Alden, Morphet and Vieira, 2013, p. 27). Brazil has always felt more comfortable in taking its proposals to the G-77 and UNCTAD spaces, in which it had an outstanding performance than the option of joining the Non-Aligned

\footnotetext{
${ }^{4}$ The group was founded on 15 June 1964 by the "Joint Declaration of the SeventySeven Countries" issued at the United Nations Conference on Trade and Development (UNCTAD). The first major meeting was in Algiers in 1967 when the Algiers Charter was adopted and the basis for permanent institutional structures was laid.
} 
Movement. It is interesting to mention the fact that during the first United Nations Conference on Trade and Development there has been a change of the political regime in Brazil since on 1 April 1964 the constitutional president João Goulart was deposed by a Military Junta. However, the new government, despite the ideological divergences with the previous administration, did not change Brazilian economic diplomacy. Therefore, at the UNCTAD, it defended essentially the previous regime proposals, which were searched for union with the other developing countries, in particular with the Latin-American group, seeking to manage the NorthSouth conflict and to minimise the divisions with the developed countries. And, no less important, to ensure the continuity of the UNCTAD through an executive body that could implement the proposals approved in Geneva. The priorities of Brazilian diplomacy (including its relationship with the Non-Aligned) did not change much during the military regime concerning the previous stage, nor did it undergo fundamental changes after 21 years of the military regime, with the return of democracy, when it could have reviewed its choice. At the beginning of the 21st century (as we will explain later), great changes took place. It is interesting to highlight that by 1973 the G-77 and NAM agendas and parallel processes had converged. The IV Summit Conference of the Non-Aligned Movement was held from 5 to 9 September 1973 in Algiers, and it is considered one of the most important NAM meetings. The final declaration points to a critical international situation characterised by the "tensions in the peripheral areas, due to the deteriorating economic conditions in developing countries." Among "the main causes of inequality, which increases permanently and afflicts the developing world" the statement mentions the "various methods of economic domination and neocolonial exploitation". The document also denounces "the transnational's and their monopolistic role in the commercial, financial and industrial plans." The scenario required drawing up policies that would lead to "the establishment of a new type of international economic relations". The call for a New International Economic Order (NIEO) united the G-77 and the NAM countries.

\section{The Brazilian perspective - the Second period}

The G-77 and UNCTAD experience placed Brazil in a prominent position among the South countries. Without having formally joined the Non-Aligned Movement, Brazil was defending an economic agenda that had many points in common with those of the NAM. In the early years of the $21^{\text {st }}$ century, after the first stage of the democratisation period 
characterised by neoliberal governments, Brazil was one of the South American countries that experienced what has already begun to be called a "golden age". Progressive governments with a broad popular base began to implement agendas aimed at overcoming the neoliberal economic legacy and strengthening regional integration, in a bold move towards autonomy concerning the historical dependence on North American hegemony. But the audacity of Brazil Workers' Party governments proved even greater when, for the first time in history, the country formalized an extra-regional alliance, as one of the promoters of the BRICS. The BRICS group tally with the (somewhat frustrated) goals of the Non-Aligned Movement. The 1970's proposal for a New International Economic Order depended, to a great extent, on agreements that could have been reached with the developed powers. In the early $21^{\text {st }}$ century, the BRICS - taking advantage of the strength of the Chinese economy and the vastness of the areas represented, Latin America, Africa, Eurasia - began to modify the rules of the macroeconomic game simply by using their resources and acting with a clear political will. For instance, instead of using the Breton Woods structuresin particular the IMF and the World Bank - the emerging powers chose to propose alternatives that did not involve an open dispute with the hegemonic powers, thus allowing them to create more inclusive conditions for global growth. This was the essence of the project of the Non-Aligned Nations when they advocated a new international economic order. The difference lies in the concrete possibilities of achieving these goals in the past and today's world. The proximity of China and Russia to the Non-Aligned Movement was already a fact at the time of the Cold War, but the rationale of that historical moment made the coordinated action difficult. It is easy to understand that an equidistant relationship with both blocs was not the idea of the major part of the NAM members. Except for one or two countries which, for historical reasons, openly or implicitly defended an alliance with the West, most of the non-aligned countries were fully aware that their potential allies were in the socialist bloc and that they could not expect any similar support from the Western bloc, which included the old colonial powers. But they could not advance much further in that bipolar world system. Now we come to the point where the perspective of the long term enables us to understand the present. That is why we pointed out at the beginning of this article that in this second decade of the $21^{\text {st }}$ century, it is important to review some of the processes that marked the $20^{\text {th }}$ century and analyse them in the light of today's problems. As aforementioned, strategies and methods used by the US to frustrate perceived challenges to its hegemony are various. In a moment defined as a New Cold War or, more 
specifically, at a time when US National Security Strategy documents defined China and Russia as America's greatest enemies, it was not difficult to understand that one of the most immediate objectives of the US administration was to break the BRICS (NSS Archive, 2019-2021). In this game, Brazil was the weakest link and the main target. Because of its size, population, natural wealth, including strategic minerals, oil, agricultural potential, and important aquifers, Brazil is a key country in South America. Where Brazil goes, so do its neighbours. This was the case with the cycle of dictatorships, inaugurated with the 1964 coup d'état in Brazil, and it was also the case with the period of re-democratisation in the 1980s. And this became clear during Brazil's active participation in the BRICS. Taking advantage of the meeting in Fortaleza, Brazil (2014), President Rousseff invited the South American heads of state to a meeting in Brasilia with the leaders of China, Russia, India, and South Africa. The photo of that meeting marked the climax of Brazil's progressive governments' diplomacy. It is important to stress that by joining the BRICS experience, Brazil took a step it had never taken before, opting to join an extra-regional alliance with an emphasis on economic issues but with an undoubted geopolitical impact. A US reaction was to be expected, aiming to get Brazil back under its sphere of influence. This reaction was reinforced and articulated in Brazil with the support of important conservative political groups, representatives of the judiciary, business leaders, and the media, particularly the Globo Network oligopoly, as proven by official US documents that were eventually leaked. The Brazilian political crisis that led to the impeachment of President Dilma Rousseff must be embedded in the context of a broader project. It was in great measure linked to a strategy aiming not only to undermine the BRICS project, but also to make Brazil back off from strategic regional alliances (UNASUR, MERCOSUR). The second stage of this strategy was the candidacy and victory of Jair Bolsonaro, delineated within military circles, as was openly stated in the book of memoirs by General Eduardo Villas Bôas, Army commander between 2015 and 2019, published in February 2021 by the Fundação Getúlio Vargas.

The experience that began in Bandung, expanded in Belgrade in 1961 with the Non-Aligned Movement, and continued with the search to strengthen international alliances that would make it possible to redesign global economic structures and democratise world political structures, is not finished. Neither is it defeated. The evolution of human society is neither linear nor predetermined. It is the conscience of the people that marks the advancement. The challenge today is complex because, in addition to the economic, social, and political agenda, there is also the environmental one. 
The legacy of past experiences is very rich. It is up to present and future generations to use it wisely. ${ }^{5}$

\section{References}

Alden, Chris, Morphet, Sally, Vieira, Marco A. (2013). The South in World Politics. Basingstoke, Palgrave Macmillan.

Lee, Cristopher J. (2011). Making a World After Empire: The Bandung Movement and its Political Afterlives. Athens, Ohio University Press.

NSS Archive -National Security Strategy Archive (2019-21). Retrieved from https://nssarchive.us/

Stanford, Ross (1976). “Third World Commodity Power is a Costly illusion”, Fortune, November.

Transcript of Monroe Doctrine (1823), retrieved from https://www.our documents.gov $/$ doc.php?flash $=$ false $\&$ doc $=23 \&$ page $=$ transcript

Wright, Richard. The Colour Curtain: A report on the Bandung Conference. (1956) Cleveland and New York, The World Publishing Company.

\footnotetext{
${ }^{5}$ The author of this analysis had worked for more than two decades as a journalist in the international arena, as a correspondent for various Latin American media outlets and as founder, editor and director of three magazines, Third World (19742005), Ecology and Development (1991-2005) and Revista do Mercosur (1992-2005). During her career as a journalist, the author personally interviewed personalities such as Nelson Mandela, Agostinho Neto, Fidel Castro, Yasser Arafat, Samora Machel, Saddam Hussein, Sean MacBride, Xanana Gusmao, Julius Nyerere, General Omar Torrijos, General Velasco Alvarado, Eduardo Galeano, Mahmoud Darwish, and collectively Muammar Gaddafi, alongside many others. She is the winner of numerous awards for journalism, including the Vladimir Herzog Prize (1987), the Golden Dolphin Award (2000) and the Victory Medal (2013), by the Brazilian Ministry of Defense.
} 